\title{
ANALISIS KANDUNGAN ENZIM DIASTASE PADA MADU SINGKONG HASIL PROSES VACUUM EVAPORATION DAN VACUUM COOLING
}

\author{
Anang Lastriyanto ${ }^{1}$, Silvi Astri Cahyani ${ }^{1}$ \\ ${ }^{1}$ Jurusan Teknik Pertanian, Fakultas Teknologi Pertanian, Universitas Brawijaya, \\ Jl. Veteran, Ketawanggede, Kec. Lowokwaru, Kota Malang, Jawa Timur 65145, Indonesia \\ Email : anangl@ub.ac.id
}

\begin{abstract}
Abstrak
Madu yang memiliki kadar air diatas $22 \%$ harus di lakukan proses pengurangan kadar air. Hal tersebut dilakukan agar madu tidak mengalami fermentasi serta memiliki masa simpan yang lebih lama. Salah satu cara yang dapat digunakan untuk mengurangi kadar air dalam madu adalah evaporasi. Evaporasi merupakan merupakan sebuah proses perubahan sebagian kandungan air dalam bahan menjadi uap dengan memanfaatkan suhu yang mendekati titik didih air. Namun kandungan minor madu seperti enzim diastase sangat peka terhadap suhu tinggi oleh karena itu digunakan evaporasi vakum agar dalam prosesnya digunakan suhu yang lebih rendah sehingga dapat meminimalisisr kerusakan enzim diastase. Metode penelitian dilakukan dengan 3 tahap, yaitu pengambilan sampel, proses evaporasi, dan pengujian sampel. Hasil penelitian ini menunjukan bahwa proses evaporasi vakum dan vacuum cooling dapat merubah kandungan proksimat madu singkong memenuhi SNI.
\end{abstract}

Keywords: Evaporasi, Vacuum, Madu, Enzim Diastase, Kadar Air

\begin{abstract}
Honey that has a moisture content above $22 \%$ should be done moisture reduction process. reduction of water content is done so that honey does not undergo fermentation and has a longer shelf life. One of the ways that can be used to reduce water content in honey is evaporation. Evaporation is of converting some of the water content in the material into steam by utilizing temperatures close to the boiling point of water. However, the minor content of honey, such as the diastase enzyme, is very sensitive to high temperatures. Therefore, vacuum evaporation is used so that the process uses a lower temperature to minimize the damage to the diastase enzyme. The research method was carried out in 3 stages, namely sampling, evaporation process, and sample testing. The results of this study indicate that the process of vacuum evaporation and vacuum cooling can change the proximate content of cassava honey to comply with SNI.
\end{abstract}

Keywords: Evaporation, Vacuum, Honey, Diastase Enzyme, Moisture Content Received: April 5, 2021 ; Accepted: July 8, 2021; Publish online: July 31, 2021

\section{Pendahuluan}

Madu merupakan sebuah produk alami yang dihasilkan dari nektar oleh lebah. Madu berbentuk cairan kental yang umumnya memiliki rasa manis karena komponen utamanya merupakan larutan gula jenuh alami yang terdiri atas campuran karbohidrat kompleks [1]. Madu juga terkenal sebagai bahan yang memiliki berbagai macam komponen minor yang bermanfaat seperti vitamin, mineral, asam amino bebas , senyawa organik, enzim, dan berbagai senyawa volatil lainnya. Rasa manis pada madu menjadikannya sering dimanfaatkan sebagai pengganti bahan pemanis ataupun sebagai obat alami mengingat banyaknya khasiat madu untuk kesehatan.

Indonesia terkenal sebagai salah satu negara penghasil madu terbanyak, namun madu hutan yang dihasilkan di Indonesia cenderung memiliki kadar air yang cukup tinggi dikarenakan termasuk wilayah tropis dimana memiliki kelembapan udara dalam rentang $60 \%$ hingga $90 \%$. Hal tersebut merupakan salah satu faktor penyebab turunnya kualitas madu, karena kadar air pada madu yang cukup tinggi dapat memicu terjadinya proses fermentasi sehingga madu dapat mengalami penurunan nilai gizi [2]. Penurunan nilai gizi tersebut ditandai dengan bertambah masamnya rasa madu serta munculnya banyak gas dalam kemasan madu.

Salah satu cara untuk meminimalisir kerusakan kandungan madu yang diakibatkan oleh tingginya kadar air pada madu adalah evaporasi. Evaporasi merupakan sebuah proses perubahan sebagian kandungan air dalam bahan menjadi uap dengan memanfaatkan suhu yang mendekati titik didih air [3]. Namun, pengolahan madu 
menggunakan suhu tinggi dapat dengan mudah merusak komponen minor yang ada dalam madu salah satunya adalah enzim. Oleh sebab itu perlu dilakukan modifikasi dalam proses evaporasi untuk madu.

Evaporasi yang digunakan dalam penelitian ini merupakan evaporasi vakum yakni evaporasi yang dapat mengubah zat cair menjadi uap dalam suhu yang relatif rendah dengan memanfaatkan tekanan dibawah atmosfer (vakum) [4]. Pengaplikasian evaporator vakum ini dapat dilakukan agar proses pengolahan madu tidak menggunakan suhu yang terlalu tinggi sehingga kandungan madu yang peka terhadap termal dapat terjaga. Setelah dilakukan proses evaporasi vakum dilanjutkan dengan proses pendinginan menggunakan vacuum cooling yang bertujuan untuk mempercepat proses pendinginan sehingga panas hasil dari proses evaporasi vakum tidak terperangkap di madu dalam waktu yang lama [5].

Proses evaporasi dan pendinginan yang dilakukan dalam keadaan vakum ini dapat meminimalisir kerusakan komponen minor yang penting dalam madu selama pengurangan kadar air. Salah satu komponen minor yang penting adalah enzim diastase. Enzim diastase berasal dari air liur lebah yang ditambahkan pada pada saat proses pematangan madu [6]. Aktivitas enzim diastase merupakan salah satu patameter yang digunakan untuk menilai kualitas madu, karena enzim diastase merupakan zat murni dari tubuh lebah [7]. Nilai minimum dari enzim diastase untuk ternak dalam SNI adalah 3 diastese number (DN). Aktivitas enzim dalam madu akan mengalami penurunan akibat dari lama penyimpanan dan proses pemanasan madu [8]. Di beberapa Negara terutama Eropa aktivitas enzim diastase digunakan sebagai salah satu indikator untuk dalam mengukur kesegaran madu.

Tujuan penelitian yang dilakukan penulis adalah mengamati perubahan aktivitas enzim diastase dan kadar air pada madu singkong pada setiap step proses pengolahan madu. Adapun proses pengolahan madu yang digunakan pada penelitian ini terdiri dari proses pasteurisasi, proses evaporasi vakum, dan proses vacuum cooling. Pada penelitian ini, peneliti menggunakan alat evaporator vacuum cooling.

\section{Bahan dan Metode Penelitian}

\section{Alat dan Bahan}

Alat yang digunakan dalam penelitian ini meliputi vacuum cooling berkapasitas 1 liter yang dilengkapi dengan automatisasi suhu, moisture analyzer untuk mengukur kadar air, stopwatch, timbangan digital, kuvet quartz, Heater Nanotech 1 ltr NT-1703, Spektrofotometer Visibel 721, timbangan digital dan peralatan pendukung lainnya. Sedangkan bahan utama yang digunakan adalah madu singkong murni yang diperoleh langsung dari peternak madu. Bahan lain yang digunakan adalah iodine, kalium iodida, aquades, asam asetat, natrium asetat, $\mathrm{NaCl}$, dan amylum soluble.

\section{Metode Penelitian}

Penelitian ini menganalisis perubahan kandungan aktivitas enzim diastase serta kadar air pada madu singkong setelah dilakukan proses evaporasi vakum serta pendinginan vakum. Metode penelitian dilakukan dengan 3 tahap, yaitu pengolahan madu, pengambilan sampel madu dan pengujian sampel madu. Pengolahan madu dilakukan dalam beberapa tahap meliputi proses pasteurisasi, proses evaporasi vakum, dan proses vacuum cooling yang dilakukan dalam 1 alat yang sama yakni vacuum cooling.

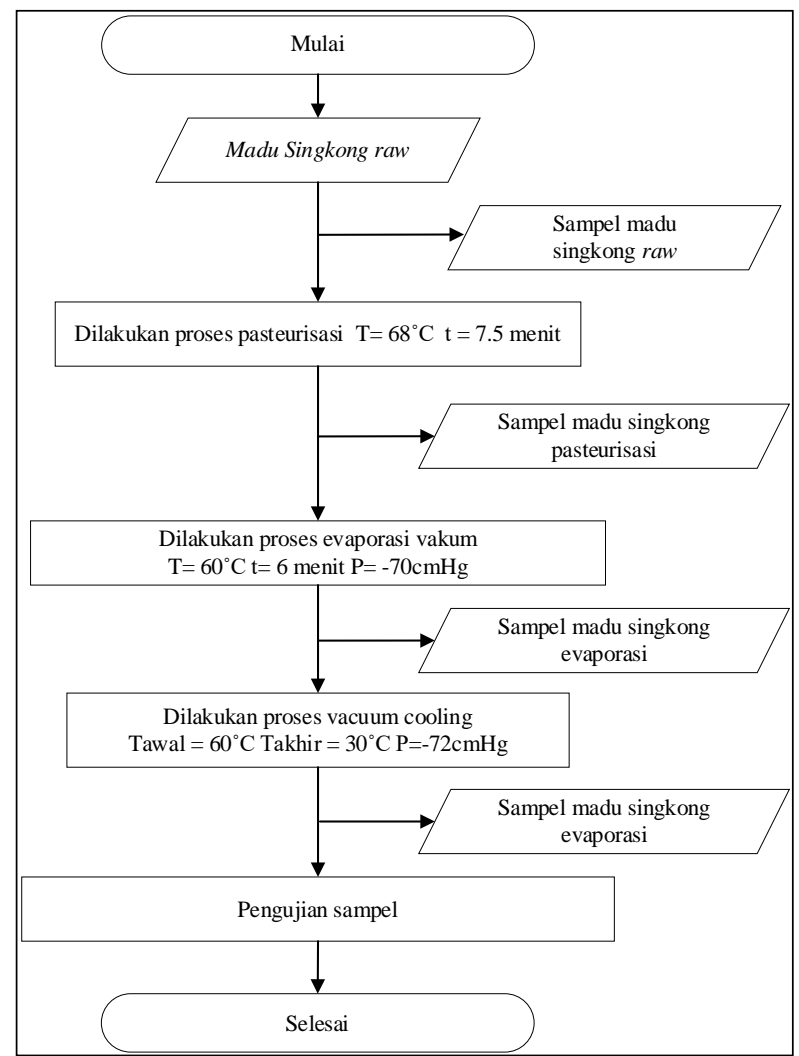

Gambar 1. Diagram alir mekanisme pengambilan data

Pengambilan sampel dilakukan di tiap proses pengolahan yakni setelah pasteurisasi, setelah evaporasi vakum, setelah vacuum cooling serta sampel raw. Sampel yang telah diperoleh dimasukkan ke dalam botol kecil kemudian ditutup rapat dan disimpan pada suhu kamar untuk menghindari perubahan sifat fisik dan kimia. Pengujian sampel dilakukan untuk mengetahui sifat fisik dan kimia madu sebelum proses penguapan dan setelah proses penguapan. Adapun pengujian terhadap sampel madu yang dilakukan pada penelitian ini yaitu kadar air dan aktivitas enzim diastase. Data uji sampel dapat digunakan untuk mengetahui seberapa besar perubahan sifat fisik dan kimia madu yang terjadi selama proses pengolahan. 


\section{Kadar Air}

Kadar air dalam sampel madu diukur menggunakan Shimadzu Moisture Analyzer MOC 120. Prinsip penggunaan penganalisis kelembapan adalah dengan memanaskan sampel madu hingga air dalam bahan menguap, dan secara otomatis menampilkan persentase kadar air sampel pada LCD. Waktu pemanasan pada moisture analyzer bergantung pada kadar air dalam sampel. Semakin tinggi kadar air dalam sampel, semakin lama waktu pemanasannya. Satuan kadar air yang digunakan adalah persentase (\%).

\section{Aktivitas Enzim Diastase}

Dalam penelitian ini, metode Schade digunakan untuk mengetahui aktivitas amilase. Bahan yang digunakan dalam pengujian ini adalah yodium, kalium iodida, akuades, buffer asetat, natrium klorida dan pati. Hal pertama yang harus dilakukan adalah melarutkan amylum soluble dalam air suling lalu memanaskannya dalam air mendidih selama 5 menit. Setelah itu siapkan pereaksi yodium yang terbuat dari campuran iodium, kalium iodida dan akuades.

Preparasi sampel pada metode Schade dilakukan dengan menimbang 5 gram sampel madu kemudian ditambahkan aquadest. Sebelum menambahkan $\mathrm{NaCl}$, sampel h sampel harus di-buffer. Selanjutnya sampel madu dan larutan pati dipanaskan pada suhu $40{ }^{\circ} \mathrm{C}$ secara terpisah selama 15 menit. Campurkan larutan kanji ke dalam sampel lalu panaskan kembali pada suhu yang sama. Setiap 5 menit selama 15 menit, ditambahkan larutan 0,5 $\mathrm{ml}$ dan campurkan ke dalam reagen. Selanjutnya pembacaan absorbansi sampel yang kontak dengan reagen menggunakan alat visible spectrophotometer 721. Panjang gelombang yang digunakan adalah $660 \mathrm{~nm}$. Data absorbansi dan waktu pemanasan digunakan untuk membuat persamaan regresi linier. persamaan regresi digunakan untuk menentukan waktu (tx) yang dibutuhkan untuk mencapai absorbansi yang ditentukan sebesar 0,235 [9]. nilai tx akan dimasukkan ke dalam persamaan berikut

Dimana,

$$
D N=\frac{60 \min x 0,1}{t x} \times 0,02 .
$$

$$
\begin{array}{ll}
D N & : \text { Nilai diastase } \\
t x & : \text { Waktu yang dibutuhkan untuk mencapai } \\
& \text { absorbansi } 0.235
\end{array}
$$

\section{Hasil dan Pembahasan \\ Kadar Air}

Kadar air pada madu merupakan salah satu faktor paling dasar dalam penentuan mutu madu. Kadar air dalam madu menurut SNI tidak diperbolehkan melebihi $22 \%$, hal tersebut dikarenakan madu yang memiliki kadar air diatas $22 \%$ akan sangat mudah untuk mengalami fermentasi serta dapat memicu pertumbuhan mikroba yang merugikan ketika dikonsumsi. Oleh sebab itu madu dengan kadar air tinggi perlu untuk dilakukan pengolahan agar kadar air dapat berkurang.

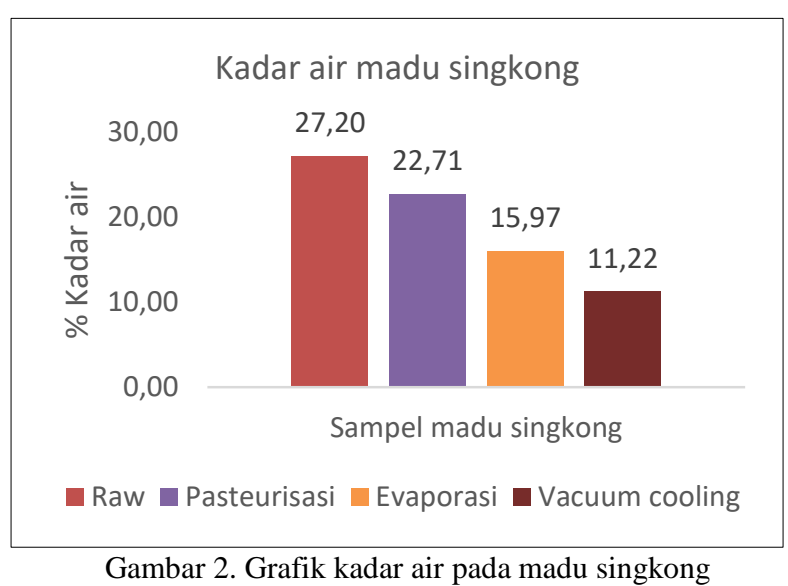

Hasil analisis kadar air pada madu singkong dapat dilihat pada Gambar 2. Kadar air tertinggi diperoleh pada sampel madu singkong raw yakni sebesar $27.20 \%$, sedangkan setelah dilakukan proses pasteurisasi diperoleh kadar air sebesar $22.71 \%$. Kedua sampel tersebut belum memenuhi SNI dikarenakan kadar air melebihi standard. Setelah dilakukan proses evaporasi vakum kadar air madu singkong mengalami penurunan yang cukup signifikan hingga diperoleh kadar air sebesar $15.97 \%$ dan setelah dilakukan proses pendinginan menggunakan vacuum cooling diperoleh kadar air sebesar $11.22 \%$. Sampel evaporasi dan vacuum cooling telah memenuhi standard SNI yakni kadar air bibawah $22 \%$.

\section{Aktivitas Enzim Diastase}

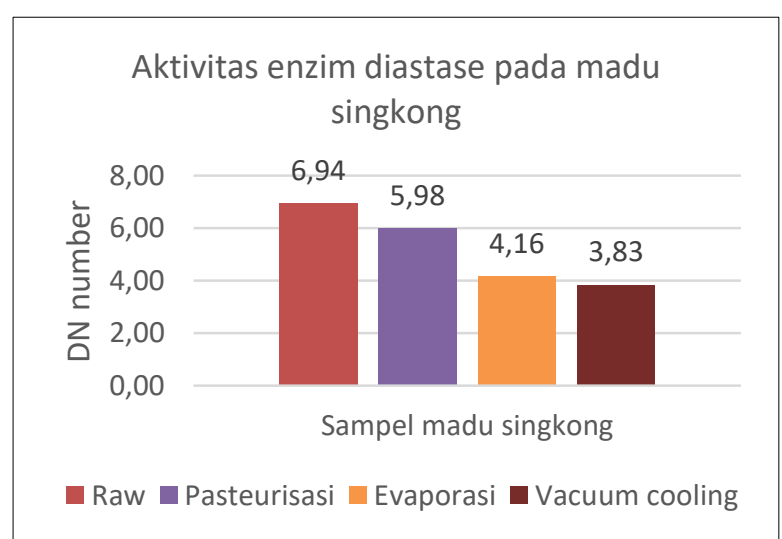

Gambar 3. Grafik aktivitas enzim diastase pada madu singkong

Hasil pengujian aktivitas enzim diastase dapat dilihat pada Gambar 3 Berdasarkan SNI madu 2018, nilai aktivitas enzim diastase tidak boleh kurang dari 3 DN untuk madu budidaya. Semua sampel madu singkong yang diuji telah memenuhi standard SNI 
karena semua sampel memiliki nilai diasstase lebih besar dari 3 DN.

Aktivitas enzim diastase pada madu singkong raw menunjukkan hasil tertinggi yakni sebesar 6.94 DN hal tersebut dikarenakan madu singkong raw tidak dilakukan proses apapun sehinga kesegaran dan kerusakan komponen nya masih sangat kecil. Sedangkan madu singkong pasteurisasi memiliki nilai diastase sebesar 5.98 DN, jika dibandingkan dengan madu singkong raw nilai diastase mengalami penurunan hal tersebut diakibatkan oleh adanya pemanasan pada proses pasteurisasi. Sampel maduf singkong evaporasi mengalami penurunan nilai diastase yang cukup tinggi hal tersebut dikarenakan pemanasan yang dilakukan pada proses evaporasi cenderung lebih lama sehingga kerusakan enzim diastase juga semakin tinggi. Sedangkan hasil pengujian pada sampel madu vacuum cooling diperoleh nilai sebesar $3.83 \mathrm{DN}$, selisih antara sampel evaporasi dan vacuum cooling tidak teralu tingi hal tersebut dikarenakan pada proses pendinginan menggunakan vacuum cooling tidak dilibatkan pemanasan melainkan pelepasan panas sehingga nilai diastase tidak mengalami penurunan yang signifikan. keterangan gambar menggunakan huruf berukuran $9 \mathrm{pt}$, bold. Jarak keterangan gambar dengan paragraf adalah dua spasi tunggal. Gambar yang telah dipublikasikan oleh penulis lain harus mendapat ijin tertulis penulisnya dan penerbitnya. Gambar akan dicetak hitam-putih.

\section{Kesimpulan}

Kesimpulan yang diperoleh dari penelitian ini yaitu proses evaporasi vakum dan vacuum cooling mampu untuk mengurangi kadar air madu hingga dibawah $22 \%$. Pengaplikasian evaporasi vakum dan vacuum cooling pada pengolahan madu singkong dapat meminimalisir kerusakan aktivitas enzim diastase yang rentan terhadap suhu tingi sehingga kerusakan enzim diastase dapat diminimalisir, Aktivitas enzim diastase pada madu singkong yang telah dilakukan pengolahan menggunakan evaporasi vakum dan vacuum cooling tetap mengalami penurunan nilai diastase meskipun tidak mengalami penurunan yang signifikan dan memenuhi SNI.

\section{Daftar Pustaka}

[1] Badan Standardisasi Nasional (BSN). Madu SNI 8664:2018 ICS 65.020.99. 2018, p. 27

[2] D. D. Wulandari. Analisa Kualitas Madu (Keasaman, Kadar Air, dan Kadar Gula Pereduksi) Berdasarkan Perbedaan Suhu Penyimpanan. J. Kim. Ris., 2(1), 2017, p. 16 doi: 10.20473/jkr.v2i1.3768

[3] H. Mutlu Ozturk, H. K. Ozturk, and G. Kocar. Comparison of Vacuum Cooling with Conventional Cooling for Purslane. Int. J. Food Eng., 7(6), 2011, doi: 10.2202/1556-3758.2442

[4] I. Alibas and N. Koksal. Forced-air, Vacuum, and Hydro Precooling of Cauliflower (Brassica
Oleracea L. Var. Botrytis cv . Freemont ): Part II . Determination of Quality Parameters During Storage. food Sci. Technol., 35(1), 2015, pp. 45-50 doi: http://dx.doi.org/10.1590/1678-457X.6457

[5] F. C. Schmidt, G. M. F. Aragão, and J. B. Laurindo. Integrated Cooking and Vacuum Cooling of Chicken Breast Cuts in a Single Vessel. J. Food Eng., 100(2), 2010, pp. 219-224 doi: 10.1016/j.jfoodeng.2010.04.002

[6] Sukmawati, A. Noor, and Firdaus. Quality Analysis of Honey Mallawa Parameters Based On Physical Chemistry. Ind. J. Chem. Res, 3(2008), 2015, pp. 259-262

[7] Z. Huang, L. Liu, G. Li, H. Li, D. Ye, and X. Li. Nondestructive Determination of Diastase Activity of Honey Based on Visible and Near-Infrared Spectroscopy. Molecules, 24(7), 2019, doi: 10.3390/molecules24071244

[8] J. Kuc, A. Grochowalski, and M. Kostina. Determination of The Diastase Activity in Honeys. Czas. Tech., 8 2017, pp. 29-35 doi: 10.4467/2353737xct.17.126.6877

[9] N. Sakač and M. Sak-Bosnar. A Rapid Method for The Determination of Honey Diastase Activity. Talanta, 93 2012, pp. 135-138 doi: 10.1016/j.talanta.2012.01.063 